\section{Palaeolithic archaeology}

\section{Pleistocene life in the dead heart of Australia}

\section{Rhys Jones}

THE first secure date for the human occupation of Australia, extending back just beyond 10,000 years (10 kyr), was obtained only 25 years ago ${ }^{1}$. The discoverer, John Mulvaney, referred to Australia as "the dark continent of prehistory". It is now known that humans occupied parts of Australia $40 \mathrm{kyr}$ ago, a date close to the limits of the conventional radiocarbon method, and evidence of occupation extending back to $20-25 \mathrm{kyr}$ ago has been established for almost all the main ecological zones of the continent (see figure). The one area that has stubbornly refused to yield such evidence beyond $10 \mathrm{kyr}$ is the core of the arid zone, which encompasses about 60 per cent of the Australian land mass in its centre and west. Some believed $^{2}$ that the Australian desert was not occupied until the end of the last Ice Age, about $10-12 \mathrm{kyr}$ ago, but that Pleistocene occupation was confined either to coastal regions or close to the banks of rivers and lakes, such as Lake Mungo, western New South Wales, which, although technically being within the arid zone, were fed by waters derived from areas with higher rainfall. Smith's demonstration, reported on page 710 of this issue ${ }^{3}$, of occupation 22 kyr ago at Puritjarra, a large rockshelter in a dunefield of the MacDonnell ranges north-west of Lake Eyre within the core of the Australian desert, finally refutes this view and, at a stroke, more than doubles the known antiquity of human occupancy of the region.

Whereas it is known that there were hominids in Java 0.7-1.0 Myr ago, there is no convincing evidence anywhere in the Indo-Malay archipelago or the adjacent mainland of South-East Asia (then joined as a contiguous Sundaland during glacial low-sea episodes) for stratified occupation sites, nor indeed for any coherent stonetool assemblages significantly older than those already obtained from greater Australia $^{4-6}$. The archaeological data support the conclusion from work on mitochondrial $\mathrm{DNA}^{7}$ that biologically modern man could have used a new technology to penetrate the South-East Asian/ Australian region $40-50$ kyr ago. This process may have been analagous with contemporaneous events in western Asia and Europe, where Neanderthalers were replaced by modern $\operatorname{man}^{8}$. In the east, it is probable that genetic interchange took place, leading to the continuation of. a distinctive regional clade, as seen in Australian fossil crania ${ }^{9}$.

Jared Diamond, in a recent News and
Views article ${ }^{i 0}$, described how only small rodents managed to cross the $100-\mathrm{km}$ wide water barriers between Asian Sunda and Australian Sahul using natural means such as vegetation rafts. Humans must have used technology that included some kind of constructed craft. The first colonists must also have had an economic system based on the exploitation of some elements of tropical lowland rainforests and shorelines, so in what is present-day New Guinea and, to a lesser extent, in northern Australia, they would have experienced familiar conditions, with many species of edible plants, fish and

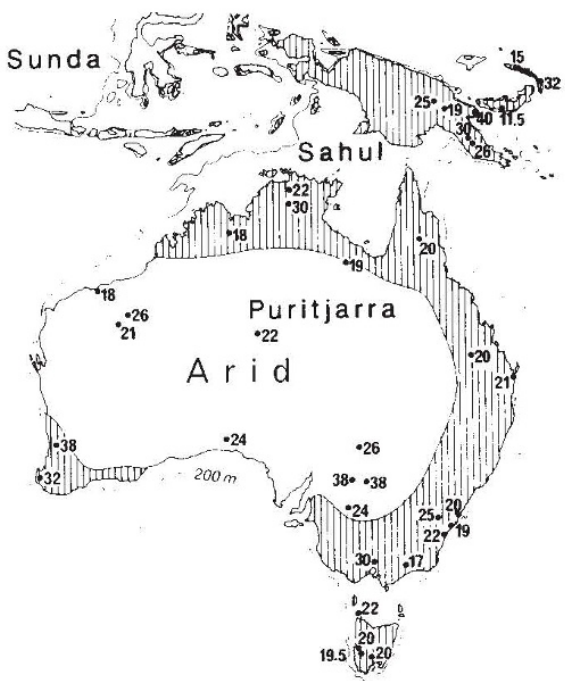

Oldest radiocarbon dates for human occupation of regions of Australia and New Guinea, expressed in kiloyears. The arid region of central Australia is defined as being within Prescott's climatic index (precipitation evaporation) $0.7-$ 1.0. Pleistocene dates for New Ireland (top right) by $\mathrm{J}$. Allen et al. (in preparation).

molluscs being common to both regions.

The earliest stone technology included large bifacial and waisted axe-like tools made of volcanic rock" ${ }^{11}$, found in New Guinea from the reef-edge coast to the highlands and in northern Australia. Groube has suggested ${ }^{11}$ that these tools were used to ring-bark rainforest trees to open up the canopy and to stimulate the growth of edible weed species such as yams, sugar cane, bananas and tree fruits. Paradoxically, having mastered the capacity to cross water, the true barrier to the colonization of the Australian continent lay not in the occupation of the tropical north but in the extension south into the dry regions of the continent. Hence the significance of Smith's discovery ${ }^{3}$ of stone artefacts dating back to the Pleistocene.
Ethnographically, the main plant staples of the desert Aborigines were grass seeds such as Panicum sp. which were ground into a flour using sandstone grinding dishes. In central Australia, none of these dishes has been found before about $4 \mathrm{kyr} \mathrm{ago}^{12}$. The original desert colonists may have had to rely on other plant foods such as the tubers of Ipomoea. There is growing evidence that late Pleistocene occupation of central arid regions of Australia was a general phenomenon, as exemplified by the basal dates of 21 and $26 \mathrm{kyr}$ from two rock shelters in the Hamersley Plateau, Western Australia ${ }^{13}$; a hearth with fresh-water mussel shells of almost $14 \mathrm{kyr}$ in the dunefields of the Strezlecki Desert ${ }^{14}$; and evidence of underground flint mining at $20 \mathrm{kyr}$ in the arid Nullarbor Plain ${ }^{15}$. Occupation continued throughout the main arid phase of the last glacial maximum. This occupation increased markedly within the past 3-4 $\mathrm{kyr}^{16,17}$, associated with the introduction of a stone-tool technology consisting of microblade and hafted flakes used as adzes, which itself might have been a reflection of other social transformations within prehistoric Aboriginal society.

The evidence found by $\mathrm{Smith}^{3}$ of red ochre associated with the 22-kyr date at Puritjarra strikes a piquant chord within the history of palaeolithic archaeology. It was Spencer and Gillen's demonstration at the end of the nineteenth century, that nomadic, stone-tool-using hunters of the desert of central Australia could also make the most profound artistic and religious creations, that prompted Salomon Reinach, the doyen of French archaeology, to propose a magico-religious function for the cave art of the Dordogne ${ }^{18}$. We now see that the distant ancestors of the Arunta Aborigines were painting at the same time as the Aurignacians, half a world away.

1. Mulvaney, D.J. Proc. Prehist. Soc. 27, 56-107 (1961)

2. Bowdler, S. in Sunda and Sahul (eds. Allen, J. et al.) 203246 (Academic, London, 1977)

3. Smith, M.A. Nature 328, 710-711 (1987)

4. Suzuki, M. et al. in Quaternary Geology of the Hominid Fossil-Bearing Formations in Java (eds. Watanabe, N. \& Kadar, D.) 309-331 (Geological Research and Development Centre, Bandung, 1985)

5. Bartstra, G.J. in Pentemuan Ilmiah Arkeologi IV (ed. Soejono, R.P.) 12-15 (National Research Inst., Jakarta, 1986).

6. Anderson, D.D. Natn. Geographic Res. 3, 184-98 (1987).

7. Cann, R.L. et al. Nature 325, 31-6 (1987).

8. Gowlett, J.A.J. Antiquity 61, 210-19 (1987)

. Thorne, A.G. \& Wolpoff, M.H. Am. J. phys. Anthrop. 55 , 337-349 (1981).

10. Diamond, J.M. Nature 327, 374 (1987)

11. Groube, L., Chappell, J., Muke, J. \& Price, D. Nature 324 453-455 (1986).

12. Smith, M.A. 1986 Occas. Pap. Northern Territory Mus. Arts Sci. 31, 123-130 (1986).

13. Brown, S. Occas. Pap. Prehist. No. 6. Australian National University 6 (1987).

14. Wasson, R.J. Z. Geomorph. 45, 85-115 (1983)

15. Wright, R.V.S. The Archaeology of the Gallus Site, Koonalda Cave (Aust. Inst. Aboriginal Studies, Canberra, 1971)

16. Lampert, R.J. Aust. Archaeol. 21, 57-62 (1985).

17. Williams, E. Recs South Austr. Mus. (in the press)

18. Reinach, S. L'Anthropologie 14, 257-263 (1903).

Rhys Jones is in the Department of Prehistory, Australian National University, PO Box 4, Canberra, ACT 2601, Australia. 